\title{
The Factors Affecting Cooperation and the Moderating Effect of Technological Turbulence
}

\author{
Arthur Tunggul Siahaan*, Eko Suhartanto, Christiana Tercia. \\ Universitas Prasetiya Mulya, Kampus Cilandak, \\ Jl. R.A. Kartini, Cilandak Barat., Cilandak, Jakarta Selatan, Jakarta 12430, Indonesia
}

\begin{tabular}{|c|c|}
\hline ARTICLE INFO & A B S T RACT \\
\hline $\begin{array}{l}\text { Keywords: } \\
\text { technological turbulence, } \\
\text { relationship marketing, } \\
\text { non-economic satisfaction, } \\
\text { business-to-business, } \\
\text { Indonesia } \\
\text { Kata Kunci: } \\
\text { turbulensi teknologi, } \\
\text { relationship marketing, } \\
\text { non-economic satisfaction, } \\
\text { business-to-business, } \\
\text { Indonesia }\end{array}$ & $\begin{array}{l}\text { This present study investigates the effect of technological turbulence } \\
\text { on cooperation, the mediation role of non-economic satisfaction } \\
\text { between focal constructs of relationship marketing (RM) and } \\
\text { cooperation, and the effect of interpersonal commitment on inter- } \\
\text { organizational commitment. The findings show that high technological } \\
\text { turbulence dampens the positive relationship of two focal constructs } \\
\text { of RM, non-economic satisfaction mediates focal constructs of RM } \\
\text { and cooperation, and interpersonal commitment influences inter- } \\
\text { organizational commitment. The study uses empirical data from } \\
\text { business-to-business (B2B) ICT resellers in Indonesia to test the } \\
\text { hypotheses developed. A structured questionnaire via an online } \\
\text { platform is used as a research instrument with one hundred and one } \\
\text { company participating. }\end{array}$ \\
\hline
\end{tabular}

SARI PATI

Penelitian ini menguji pengaruh turbulensi teknologi terhadap kooperasi, peran mediasi non-economic satisfaction terhadap konstruk utama relationship marketing (RM) dan kooperasi, serta pengaruh komitmen interpersonal (antarindividu) terhadap komitmen interorganizational (antarorganisasi). Hasil penelitian menunjukkan bahwa turbulensi teknologi yang tinggi akan mengurangi hubungan positif dua konstruk utama RM, non-economic satisfaction menengahi dua konstruk utama RM dan kooperasi, dan komitmen antarindividu mempengaruhi komitmen antarorganisasi. Untuk menguji hipotesis, penelitian ini menggunakan data empiris reseller business-to-bussines (B2B) industri ICT di Indonesia. Kuesioner dilakukan secara daring (online) dan melibatkan seratus satu perusahaan. 


\section{INTRODUCTION}

In the era of fast-changing technology, cloud-first offerings, a recurring, subscription-based model characterized by adoption and customer success, cooperation with channel partners is critical for a successful journey. With these changes, manufacturers compete to get a substantial portion of channel partners' resources while channel partners (resellers) are also juggling to catch up with the latest technology. In addition, resellers keep on building new partnerships with new manufacturers to gain more benefits even though if the offerings are competing. In this context, an established relationship between the existing manufacturer and the resellers (channel partners) may no longer be an effective way to drive the expected outcome. This phenomenon shows a change in the effectiveness of cooperation of an established relationship.

Successful relationship marketing (RM) is pertinent to cooperation (Morgan and Hunt, 1994). They define RM as marketing activities channeled toward the establishment, development, and maintenance of successful relational exchanges. Their research shows that for successful cooperation to occur, two key constructs must be present. These two key constructs are relationship commitment and trust. Cooperation as a relationship outcome that is affected directly by the two key constructs advances relationship marketing success (Morgan and Hunt, 1994). In addition, cooperation as the dyadic outcome fosters value creation (Palmatier, et al., 2006) that needs to be nurtured for a stronger partnership.

Technological turbulence as a critical dimension of environmental uncertainty (Chen, et al., 2015) may change the cooperation effectiveness of established partnerships. This technological turbulence is defined by Jaworski and Kohli (1993) as the pace of changes in technology. Tzempelikos and Kooli (2018) argue that successful RM will absorb the effect of technological turbulence. Nonetheless, Terawatanavong, et al. (2011) argue that technological turbulence may attenuate RM output and in addition, Moorman et al. (1992) argue that the turbulence may potentially hold focal constructs' positive relationship. The importance of identifying technological turbulence as one of the quickly changing market conditions is also suggested for further research by Geyskens, et al. (1999). The present study will follow Moorman et al. (1992) that examines the effect of technological turbulence to the key constructs of RM (interorganizational trust and interorganizational commitment). Furthermore, the current study also considers the possible changes in cooperation effectiveness from an established partnership triggered by technological turbulence.

Non-economic satisfaction (NES) is equally important. Svensson, et al. (2010) argue that NES as a state of overall affection that represents complacency between manufacturer and reseller is a critical factor between the two key constructs and important outcomes. In addition, Ferro, et al. (2016) reveal that NES as intangible attributes, such as content and happiness, is driven primarily by economic satisfaction. Economic satisfaction may lead to an increase in the two key constructs that ultimately leads to NES (Ferro, et al., 2016). They empirically test economic satisfaction and NES as independent variables in manufacturer-supplier relationship. Hogevold, et al. (2020) build their research based on Ferro, et al. (2016) in business relationship from seller perspective. Nonetheless they confine their empirical test to NES in the maintenance phase. Considering the importance of non-economic satisfaction and its relationship to cooperation, thus the current study extends the empirical test to institutionalization phase (cooperation).

Foreign manufacturers (manufacturers) sell new technologies and subscription-based offerings to buyers through resellers in countries, including cross-cultural countries such as Indonesia, part of ASEAN countries. In a cross-cultural context, cooperation as a result of a successful partnership starts from an interpersonal relationship (Phan et 
al., 2005). The inclusion of interpersonal relationship in $\mathrm{B} 2 \mathrm{~B}$ context is critical and requires research to factor in the measurement of interpersonal and interorganizational levels in $\mathrm{B} 2 \mathrm{~B}$ research (Mavondo and Rodrigo, 2001; Pesamaa et al., 2013). Considering the importance of interpersonal relationships, thus the present study factors it in.

RM has been studied and empirically tested in driving cooperation in multiple industries, such as US tire dealers (Morgan and Hunt, 1994) and small-to-medium-sized Norwegian manufacturers (Svensson, et al., 2010). The present study examines cooperation from the perspectives of resellers (channel partners/systems integrators) of businessto-business (B2B) information and communication technology (ICT) industry in Indonesia.

Looking at the importance of relationship marketing in the context of B2B ICT in Indonesia, this present study aims to contribute to existing theory and research. First, it examines technological turbulence as a moderating factor between two focal constructs of RM, i.e., interorganizational trust and interorganizational commitment. Second, it examines the effect of non-economic satisfaction in driving cooperation while mediating two focal constructs of RM, i.e., interorganizational trust and interorganizational commitment and cooperation construct. Third, it examines the influence of interpersonal relationships (interpersonal commitment) on interorganizational relationships (interorganizational commitment). Few studies examine the effect of technological turbulence on two RM's focal constructs, the influence of NES on cooperation, and interpersonal relationship on interorganizational relationship in the fast-changing technology B2B ICT industry in Indonesia.

There are one hundred and thirty-eight resellers (channel partners) with diverse revenues per year in the business-to-business (B2B) ICT industry in Indonesia as the scope of this research. Table 1 shows that more than $85 \%$ of respondents' titles are GM, Director, and CEO, with more than 50\% are above IDR 100 billion (approximately US\$ 6.9 million) in revenues.

This paper will be structured in this following order: literature review, conceptual framework and hypotheses, methodology, model fit, discussion, conclusion, and limitations and suggestions.

\section{Literature Review}

The presence of interorganizational trust (trust) and interorganizational commitment (commitment) as key relationship constructs are required for successful RM (Morgan and Hunt, 1994). The definition of interorganizational commitment in this study is based on Morgan and Hunt (1994) that an exchange partner believes the importance of ongoing relationship to maintain ultimately. The definition of interorganizational trust in this study is based on Zaheer et al. (1998) that is the reach of trust put in the reseller by the members of manufacturer. The interaction between these two key constructs extensively studied is from the work of Morgan and Hunt (1994). Recent studies support this interaction with empirical test (Ferro, et al., 2016; Hogevold, et al., 2020). From the previous studies, the present study supports interorganizational trust (trust) and interorganizational commitment (commitment) as two focal constructs that should be present for successful RM.

The rate of new offerings and technologies represents the rate of technological turbulence (Jaworski and Kohli, 1993). In high turbulence, a strategy in building close relationship with key partners (established partnership between manufacturer and reseller) to drive cooperation may not be effective (Song, et al., 2005; Terawatanavong, et al., 2011). The phenomenon that may dampen established successful business-to-business relationships is whenever many new foreign manufacturers (makers) with new offerings/technologies enter the market and fill the industry. This situation pointed out by Song, et al. is where the whole industry is affected by high technological turbulence, and by Christensen (1993) is where new firms (entrant 
makers/manufacturers) that are entering an industry introduce new technologies/offerings into business, rather than by the established ones. These entrant makers introduce their initial product into the industry by taking advantage of new technology while established makers utilize earlier technology (Christensen, 1993). Entrant makers may build a partnership with resellers of established makers to reach resellers' buyers and build new capability. In this context, successful cooperation between established makers and reseller may no longer be as effective. High technological turbulence that leads to relationship complacency is indeed a hurdle to the effectiveness of an established relationship between manufacturer and reseller (buyer and market-oriented supplier) (Terawatanavong, et al., 2011). Therefore, this present research will examine technological turbulence as a moderating factor between the two RM's focal constructs.

In a context of high technological turbulence, cooperation between established makers and resellers may no longer be as effective that leads to destructive response strategies (exit or neglect) (Geyskens and Steenkamp, 2000). When successful cooperation, an expected outcome of the partnership, becomes less effective, noneconomic (social) satisfaction may revert and lead to future economic benefits (by generating debts of reciprocity) of these relations (Dwyer et al., 1987; Geyskens and Steenkamp, 2000). NES in this present study, defined by Geyskens and Steenkamp (2000, p.13) as "a channel member's evaluation of the psychosocial aspects of its relationship, in that interactions with the exchange partner are fulfilling, gratifying, and facile." Previous studies have shown the importance of NES. Some argue NES as a critical relationship outcome (Farrelly and Quester, 2005; Ferro, et al., 2016; Hogevold, et al., 2020), some as a mediator at a level with two RM's key constructs, i.e., interorganizational trust and interorganizational commitment (Palmatier, et al., 2006), and some as a mediator between the two RM's key constructs with important outcomes' constructs (Svensson, et al., 2010). Based on these previous studies, the present study positions non-economic satisfaction as a mediator between two RM's focal constructs with cooperation, one of the critical outcomes.

As interorganizational relationships start with interpersonal relationships (Mavondo and Rodrigo, 2001), the inclusion of interpersonal relationships in business-to-business marketing is of great significance. Their research shows that interpersonal relationship is critical to $\mathrm{B} 2 \mathrm{~B}$ business in China. Crosby, et al. (1990) argue the importance of building an interpersonal relationship by examining how established interpersonal relationship affect commitment and dependency on the life insurance provider. Moreover, Phan, et al. (2005) argue that partnership failure due to managers' inability to maintain a successful relationship at an interpersonal level. Furthermore, Palmatier, et al. (2006) argue that RM strategies focus on the interpersonal level are more effective than those focus on the customer-firm level. The present study focuses on interpersonal commitment, defined by Mavondo and Rodrigo (2001, p. 112) as "the dedication to a long-term interpersonal relationship of individual A (representing company A) with individual B (representing company B)." Mavondo and Rodrigo (2001) link interpersonal commitment to $\mathrm{RM}$ constructs through interorganizational commitment. Their study examines interpersonal commitment construct as an antecedent to interorganizational commitment. This present study examines the effect of interpersonal commitment to the manufacturer-reseller relationship through interorganizational commitment in B2B ICT industry in Indonesia.

Cooperation, defined as interorganizational coordinated actions to achieve a mutual goal, is critical for future economic outcomes (Andersen and Narus, 1990). Through coordinated and complementary actions between manufacturer and reseller, cooperation leads to this mutual-goal achievement (Palmatier, et al., 2006). Another study identifies and examines cooperation, coordination and continuity as important outcomes' constructs 
(Svensson, et al., 2010). As coordination implies cooperation (Morgan and Hunt, 1994; Palmatier, et al., 2006) and continuity is not part of the dyadic outcome but customer-focused (Palmatier, et al., 2006), the present research positions cooperation as a critical dyadic outcome in the manufacturerreseller relationship.

\section{Conceptual Framework and Hypotheses}

Figure 1 shows a research model of the manufacturerreseller relationship with a demarcation of interpersonal and interorganizational level and a moderating factor. One construct at interpersonal level, interpersonal commitment, is proposed as antecedent of interorganizational commitment at interorganizational level. As relationships between firms would involve both individual and organizational level or interpersonal and interorganizational level (Mavondo and Rodrigo, 2001; Pesamaa et al., 2013), the link between the two is between interpersonal commitment and interorganizational commitment. The research model at the interorganizational level consists of four constructs, i.e., two RM's focal constructs, interorganizational trust and interorganizational commitment, NES, and cooperation. NES has a mediating role between the two RM's focal constructs and cooperation.

The effect of technological turbulence is examined as a moderating factor between two RM's focal constructs (interorganizational trust and interorganizational commitment). The following section discusses the constructs of the manufacturer-reseller research model and moderating effect model in Figure 1.

\section{Interpersonal Commitment and Interorganizational Commitment}

The relationship between interpersonal and interorganizational level is through interorganizational commitment and interpersonal commitment. Interorganizational relationship that includes trust, commitment, and power, is examined as mediating factors between interpersonal relationships and supply chain integration (Wang et al., 2016). Their study provides insights into the development of interorganizational relationships through interpersonal relationships. In more specific factors in the relationship, the influence of interpersonal commitment to resource-sharing activities will build stronger relationships that lead to interorganizational commitment development (Pesamaa et al., 2013). This relationship is supported empirically from an extant study (Mavondo and Rodrigo, 2001). Thus authors argue that:

H1: There is a positive relationship between interpersonal commitment and interorganizational commitment.

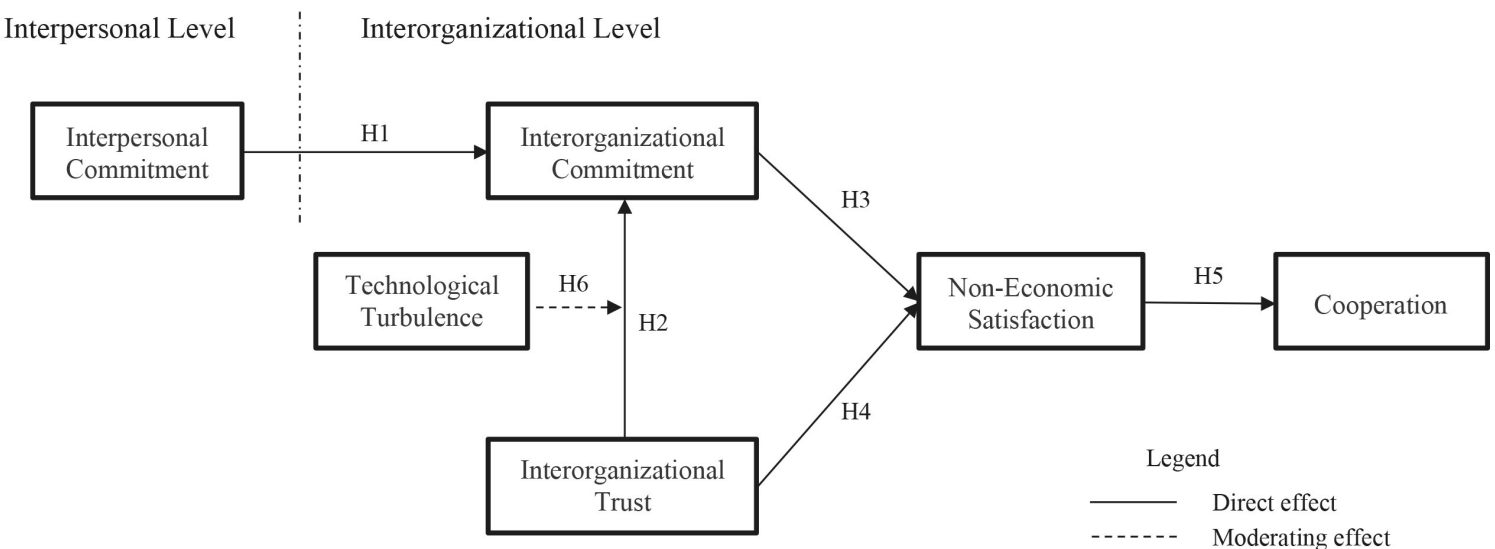

Figure 1. Manufacturer-reseller-relationship research model 
Interorganizational Trust and Interorganizational Commitment

As successful RM requires interorganizational trust and interorganizational commitment (Morgan and Hunt, 1994), these two focal constructs need to be present in business relationships. Because commitment between two organizations involves vulnerability, a partnership would occur only with trustworthy partners. Therefore trust precedes commitment (Morgan and Hunt). This relationship is also supported empirically from many extant and recent studies (Farrelly and Quester, 2005; Ferro, et al., 2016; Hogevold, et al., 2020). Following these studies, thus authors argue that:

$\mathrm{H} 2$ : There is a positive relationship between interorganizational trust and interorganizational commitment.

\section{Interorganizational Trust and NES}

NES will have a more critical role in business-tobusiness relations (Dwyer et al., 1987; Geyskens and Steenkamp, 2000). This current study examine NES construct as a mediating factor between two RM's key constructs with cooperation. The relationship between interorganizational trust and NES will be tested empirically. Trusting manufacturers and resellers (channel partners) work together with open communication may lead to the fulfilment of NES (Farrelly and Quester, 2005; Hogevold, et al., 2020). The presence of interorganizational trust leads to non-economic satisfaction is tested empirically from earlier and recent studies (Farrelly and Quester, 2005, Ferro, et al., 2016, Hogevold, et al., 2020). As such, the authors offer the following hypothesis:

H3: There is a positive relationship between interorganizational trust and NES.

\section{Interorganizational Commitment and NES}

Manufacturers and resellers would believe that the ongoing relationship is worth to be maintained due to its significance to their success. The level of commitment developed would create a conducive atmosphere to achieve individual and mutual goals that stimulate NES (Farrelly and Quester, 2005). The presence of interorganizational commitment leads to non-economic satisfaction is tested empirically from earlier and recent studies (Farrelly and Quester, 2005; Ferro, et al., 2016, Hogevold, et al., 2020). However, the result of this relationship varies. Farrelly and Quester (2005) could not find significant relationship between the two constructs, while Ferro, et al. (2016) and Hogevold, et al. (2020) could. Accordingly, the authors argue that:

H4: There is a positive relationship between interorganizational commitment and NES.

\section{NES and Cooperation}

One of the outcomes that are influenced the most by relationships is cooperation (Palmatier, et al., 2006). In their research, customer relationships do not influence all outcomes equally. They also find that cooperation as one of the outcomes is the most influenced. It shows how critical cooperation is as a dyadic outcome in relationship marketing (Palmatier, et al., 2006). NES (satisfaction) has been tested empirically and positioned as a mediator between two RM's focal constructs interorganizational trust (trust) and interorganizational commitment (commitment), with one of important outcomes of the relationship (i.e. cooperation) (Svensson, et al., 2010). Accordingly, authors argue that:

H5: There is a positive relationship between NES and cooperation.

Technological Turbulence as Moderating Factors Extant research finds that building a close relationship is less effective in performance in high technological turbulence (Terawatanavong, et al., 2011). Moreover, the effect of marketing-related capabilities on performance is decreasing in more technologically turbulent environment (Song, et al., 2005). In this context, reliance on a market-oriented firm (supplier) leads to relationship complacency and resistance to innovation that may drive unwillingness to take a different approach of previously 
established cooperation (routines and interaction) (Terawatanavong, et al., 2011). In this high technological turbulence, building close relationships alone may potentially lead to less effective cooperation. As the relationship, characterized by the presence of two RM's focal constructs, i.e., interorganizational trust and interorganizational commitment, a positive relationship between these two focal constructs may get dampened. Therefore, the authors argue that:

H6: The stronger the technological turbulence, the weaker positive relationship between interorganizational trust and interorganizational commitment.

\section{METHODS}

\section{Sample and Data Collection}

This research starts with exploratory fieldwork. Face-to-face interviews through virtual meeting platforms with business-to-business managers (director level) are initiated. Seven interviews from seven resellers are confirmed and scheduled in a nine-day timeframe. Six interviews, conducted and recorded by virtual meeting platform, are completed, except one interview, due to business reasons. Each interview lasts between 45 to 60 minutes and is complete in June 2020. The recorded session is replayed immediately or before the next interview schedule to transcribe manually and identify aspects of business-to-business manufacturer-reseller relationships and what triggers the effectiveness changes in cooperation. Based on these interviews, the authors prepare the first English with an Indonesian-translated questionnaire draft. English and Indonesian questionnaires, reviewed by top-management-level respondents (CEOs or directors of the company), are finalized. Five top-management-level respondents from five companies pre-test English questionnaires. The final modified translated questionnaire, tested and reviewed without challenges by next two topmanagement-level respondents, is concluded and ready for wide distribution.

An online-platform questionnaire is selected for data gathering to reach wider audience. Questionnaires, sent to 175 respondents from 138 diverse companies in B2B ICT industry in Indonesia, are complete in less than 30 days (July - August 2020). One hundred and thirty-eight respondents from 101 companies respond and fill in the questionnaires. Respondents, listed in Table 1 with roles at the top management level (CEO or director) or general management level (sales, finance, engineering/architecture and product/marketing), participate in this present study. Out of 138 responses collected, there are 15 responses discarded due to missing data with the following details: one response with more than $80 \%$ no answers, seven responses not being engaged, and another seven responses are considered significant outliers. A total of 123 responses are measured.

Tabel 1. Sample Description

\begin{tabular}{ll}
\hline Sample characteristics & $\%$ \\
\hline Respondent Titles & Total $(\mathrm{n}=138)$ percent \\
CEO & 24.6 \\
Director & 31.2 \\
GM & 29.7 \\
Other & 14.5 \\
Annual revenues & Total $(\mathrm{n}=137)$ percent \\
$<=$ IDR 25 billion & 19.0 \\
IDR 25 - 99.9 billion & 27.0 \\
IDR 100 - 499 billion & 19.7 \\
IDR 500 - 999 billion & 5.8 \\
IDR 1 - 2.9 trillion & 25.5 \\
$>=$ IDR 3.0 trillion & 3.0
\end{tabular}

Note: US\$ 1 = IDR 15,000 in August 2020; 1 respondent did not fill in annual revenue information, so $n=137$ for annual revenues

\section{Measurement}

All measured items are in a seven-point Likert-type format $(1=$ strongly disagree, $4=$ neither agree nor disagree, 7 = strongly agree) and analyzed for validity and reliability. The resulting measurement model is $\chi^{2}=199.54, \mathrm{df}=154, \mathrm{p}=0.008$. Appendix A1 contains measurement items, factor loadings, and Cronbach's alpha. A brief of origin of the measures used in this present study is as follows: 
Tabel 2. Goodness-of-Fit Indices

\begin{tabular}{llll}
\hline Goodness-of-fit test & $\begin{array}{l}\text { Measurement } \\
\text { research model }\end{array}$ & $\begin{array}{l}\text { Structural } \\
\text { research model }\end{array}$ & Note \\
\hline Chi-square & $199.54(p=0.008)$ & $147.24(p=0.017)$ & $\begin{array}{l}p \text {-value is significant using } \\
\text { a type I error rate of } 0.05\end{array}$ \\
\hline Degree of freedom $(d f)$ & 154 & 113 & \\
\hline Normed Chi-square $\left(\chi^{2} / d f\right)$ & 1.3 & 1.3 & \\
\hline
\end{tabular}

\begin{tabular}{llll} 
Absolute Fit Measures & & & \\
\hline Goodness-of-fit index (GFI) & 0.87 & 0.89 & higher value better fit \\
\hline $\begin{array}{l}\text { Root mean square error of approximation } \\
\text { (RMSEA) }\end{array}$ & 0.05 & 0.05 & $<0.08$ \\
\hline 90 percent confidence interval for RMSEA & $0.03-0.07$ & $0.02-0.07$ & $<0.08$ \\
\hline Normed chi-square & 1.3 & 1.3 & $<2.0$ very good \\
\hline Incremental Fit Indices & & & 0.95 or better \\
\hline Tucker Lewis Index (TLI) & 0.95 & 0.95 & 0.95 or better \\
\hline Comparative fit index (CFI) & 0.96 & 0.96 & higher value better fit \\
\hline Parsimony Fit Indices & & &
\end{tabular}

Interorganizational trust. Items are from Zaheer et al. (1998), borrowed and modified with two components of trust: reliability and fairness.

Interorganizational commitment. Items borrowed and modified are from Morgan and Hunt (1994). The measure includes the importance of a relationship to resellers (as respondents) and how resellers' beliefs about maintaining valued relationships (Morgan and Hunt, 1994).

Interpersonal commitment and cooperation. Items borrowed and modified are from Mavondo and Rodrigo (2001). Mutual benefits and longterm orientation measured are for interpersonal commitment, while resource/information sharing and joint action measured are for cooperation.

Non-economic satisfaction. Items are from Rodriguez, et al. (2006), borrowed and modified with interactive experiences component.

Technological turbulence. Items are from Jaworski and Kohli (1993), borrowed and modified with a state of flux of technology component.

\section{Model Fit}

The measurement model of 6 constructs and 20 indicators of manufacturer-reseller relationship is examined and tested using CFA and followed by SEM to test structural properties between 5 constructs with their 17 indicators. Structural equation modeling (SEM) used in this research is SPSS/AMOS version 26 software. Our research model shows satisfactory findings. The goodnessof-fit statistics of measurement and structural model are within the $(\mathrm{N}<250$ and $12<\mathrm{m}<30$, $\mathrm{N}$, and $\mathrm{m}=$ number of samples and indicators respectively) guideline (Hair, et al., 2014, pp. 578584) and shown in Table 2. Goodness-of-fit indices difference between measurement and structural model is due to a difference in the total number of constructs (technological turbulence construct as moderating factor not factored in the structural model) and relationships.

\section{RESULTS}

The summary of construct reliability is shown in Appendix A1. Cronbach's alpha value of each individual construct is equal to and higher than 0.7 , ranging from 0.7 to 0.83 . Factor loadings exceed 0.5 , 
ranging from 0.51 to 0.91 . AVE values exceed 0.5 , ranging from 0.53 to 0.64 . The composite reliability (CR) of all included constructs is above 0.7 , ranging from 0.70 to 0.84 , indicates reliability. Table 3 shows CR, AVE and the square root of AVE. The measurement properties of the structural research model show a satisfactory model fit, validity, and reliability.

\section{Hypotheses Testing}

The present study tests the model in Figure 1 with the following results. Hypothesis 1 (H1) tests the influence of interpersonal commitment on interorganizational commitment, and the result indicates that interpersonal commitment positively and significantly affects interorganizational commitment $(\mathrm{b}=0.67, \mathrm{p}<0.001)$. Hypothesis 2 (H2) tests the focal constructs relationship of interorganizational trust to interorganizational commitment, and the result indicates that interorganizational trust positively and significantly affects interorganizational commitment $(b=0.34$, $\mathrm{p}<0.001)$. Hypothesis $3(\mathrm{H} 3)$ tests the influence of interorganizational trust on NES, and the result indicates that interorganizational trust positively and significantly affects NES $(b=0.34$, $\mathrm{p}<0.001)$. Hypothesis $4(\mathrm{H} 4)$ tests the influence of interorganizational commitment on NES, and the result indicates that interorganizational commitment positively and significantly affects
NES $(b=0.60, p<0.001)$. Hypothesis 5 (H5) tests the influence of NES on cooperation, and the result indicates that NES positively and significantly affects cooperation $(b=0.51, p<0.001)$. The direct effects of each relationship ( $\mathrm{H} 1$ - $\mathrm{H} 5)$ in manufacturerreseller B2B relationship structural research model are significant at $\mathrm{p}<0.001$ with standardized regression weights ranging between 0.34 and 0.67 and summarized in Table 4.

The findings also support 4 of 4 indirect paths with standardized regression weights ranging between 0.18 and 0.40 with significant indirect paths at $\mathrm{p} \leq 0.01$, as summarized in Table 4. Therefore two mediations are allowed. First, non-economic satisfaction fully mediates interoganizational trust and interorganizational commitment with cooperation. Second, interorganizational commitment fully mediates interpersonal commitment and noneconomic satisfaction.

\section{Interaction Effect}

Hypothesis 6 (H6) tests the interaction effect of technological turbulence, as a moderator, to interorganizational trust and interorganizational commitment. H6 tests whether the stronger the technological turbulence, the weaker positive relationship between interorganizational trust and interorganizational commitment. The result indicates that technological turbulence negatively

Tabel 3. Inter construct correlations matrix

\begin{tabular}{|c|c|c|c|c|c|c|c|c|}
\hline Constructs/Dimension & CR & AVE & 1 & 2 & 3 & 4 & 5 & 6 \\
\hline $\begin{array}{r}\text { 1. Interpersonal } \\
\text { Commitment }\end{array}$ & 0.82 & 0.54 & 0.74 & & & & & \\
\hline $\begin{array}{l}\text { 2. Interorganizational } \\
\text { Commitment }\end{array}$ & 0.82 & 0.54 & $0.70 * * *$ & 0.73 & & & & \\
\hline $\begin{array}{l}\text { 3. Interorganizational } \\
\text { Trust }\end{array}$ & 0.77 & 0.53 & $0.22 *$ & $0.46^{* * *}$ & 0.73 & & & \\
\hline $\begin{array}{l}\text { 4. Non-economic } \\
\text { Satisfaction }\end{array}$ & 0.78 & 0.53 & $0.52 * * *$ & $0.72 * * *$ & $0.62 * * *$ & 0.74 & & \\
\hline 5. Cooperation & 0.80 & 0.58 & $0.38 * * *$ & $0.41 * *$ & $0.35^{* *}$ & $0.50 * * *$ & 0.76 & \\
\hline 6. Turbulence & 0.84 & 0.64 & $0.59 * * *$ & $0.37 * *$ & $0.2 \dagger$ & $0.44 * * *$ & 0.14 & 0.80 \\
\hline
\end{tabular}

Notes: $\mathrm{N}=123 ; \mathrm{CR}=$ composite reliability, $\mathrm{AVE}=$ average variance extracted; correlation coefficients are included in the lower triangle of the matrix; the square root of AVE is on the diagonal; $\nmid \mathrm{p}<0.100 * \mathrm{p}<0.05 ; * * \mathrm{p}<0.01 ; * * * \mathrm{p}<0.001$ 
Tabel 4. Summary of the structural research model

\begin{tabular}{|c|c|c|c|c|c|c|c|}
\hline Hypothesis & \multicolumn{5}{|c|}{ The Relationship } & $\begin{array}{l}\text { Regression } \\
\text { Weight }\end{array}$ & Findings \\
\hline \multicolumn{8}{|l|}{ Direct Effect } \\
\hline $\mathrm{H} 1$ & \multicolumn{2}{|c|}{ Interpersonal commitment } & \multicolumn{3}{|c|}{$\rightarrow$ Interorganizational commitment } & $0.67 * * *$ & Supported \\
\hline $\mathrm{H} 2$ & \multicolumn{2}{|c|}{ Interorganizational trust } & \multicolumn{3}{|c|}{$\rightarrow$ Interorganizational commitment } & $0.34 * * *$ & Supported \\
\hline $\mathrm{H} 3$ & \multicolumn{2}{|c|}{ Interorganizational trust } & \multicolumn{3}{|c|}{$\rightarrow$ Non-economic satisfaction } & $0.34 * * *$ & Supported \\
\hline $\mathrm{H} 4$ & \multicolumn{2}{|c|}{$\begin{array}{l}\text { Interorganizational } \\
\text { commitment }\end{array}$} & \multicolumn{3}{|c|}{$\rightarrow$ Non-economic satisfaction } & $0.60 * * *$ & Supported \\
\hline $\mathrm{H} 5$ & \multicolumn{2}{|c|}{ Non-economic satisfaction } & \multicolumn{3}{|c|}{$\rightarrow$ Cooperation } & $0.51^{* * *}$ & Supported \\
\hline \multicolumn{8}{|c|}{ Interaction Effect } \\
\hline $\mathrm{H} 6$ & \multicolumn{2}{|c|}{$\begin{array}{l}\text { Interorganizational trust } \mathbf{x} \\
\text { technological turbulence }\end{array}$} & \multicolumn{3}{|c|}{$\rightarrow$ Interorganizational commitment } & $-0.20 * * *$ & Supported \\
\hline \multicolumn{8}{|c|}{ Indirect Effect } \\
\hline \multicolumn{2}{|c|}{ Interpersonal commitment } & \multicolumn{2}{|c|}{$\rightarrow \begin{array}{l}\text { Interorganizational } \\
\text { commitment }\end{array}$} & & $\begin{array}{l}\text { Non-economic } \\
\text { satisfaction }\end{array}$ & $0.40 * * *$ & \\
\hline \multicolumn{2}{|c|}{ Interorganizational trust } & \multicolumn{2}{|c|}{$\rightarrow \begin{array}{l}\text { Non-economic } \\
\text { satisfaction }\end{array}$} & $\rightarrow$ & Cooperation & $0.18^{* * *}$ & \\
\hline \multicolumn{2}{|c|}{$\begin{array}{l}\text { Interorganizational } \\
\text { commitment }\end{array}$} & \multicolumn{2}{|c|}{$\rightarrow \begin{array}{l}\text { Non-economic } \\
\text { satisfaction }\end{array}$} & $\rightarrow$ & Cooperation & $0.30 * * *$ & \\
\hline \multicolumn{2}{|c|}{ Interpersonal commitment } & $\rightarrow \begin{array}{l}\text { Interorg } \\
\text { commit }\end{array}$ & $\begin{array}{l}\text { zational } \\
\text { nt }\end{array}$ & $\rightarrow$ & $\begin{array}{l}\text { Non-economic } \\
\text { satisfaction }\end{array} \rightarrow$ & $0.40 * * *$ & \\
\hline
\end{tabular}

and significantly affects the interaction between interorganizational trust and interorganizational commitment $(\mathrm{b}=-0.2, \mathrm{p}<0.001)$. The interpretation of this interaction effect presented with the simple slope analysis is for understanding the interaction result, shown in Figure 2. The finding shows that technological turbulence dampens the positive relationship between interorganizational trust and interorganizational commitment. This result indicates a positive relationship is intact between interorganizational trust and interorganizational commitment during low technological turbulence. However, when technological turbulence is getting stronger, the result shows that the positive relationship between interorganizational trust and interorganizational commitment is weaker. This result may also suggest that manufacturerreseller partnerships strengthen collaboration in low technological turbulence. However, in high technological turbulence, hurdles to overcome in the collaboration need to be expected.

\section{Discussion}

This present research examines the interaction effect of technological turbulence as a moderating factor between interorganizational trust and interorganizational commitment. The finding shows that high technological turbulence dampens the positive relationship between interorganizational trust and interorganizational commitment. For cooperation to happen, trust and commitment must be present (Morgan and Hunt, 1994). As high technological turbulence dampens the positive relationship, manufacturer-reseller relationships may experience less effective cooperation in the B2B ICT industry in Indonesia. This result is consistent with previous research (Song, et al., 2005; Terawatanavong, et al., 2011), which argues 


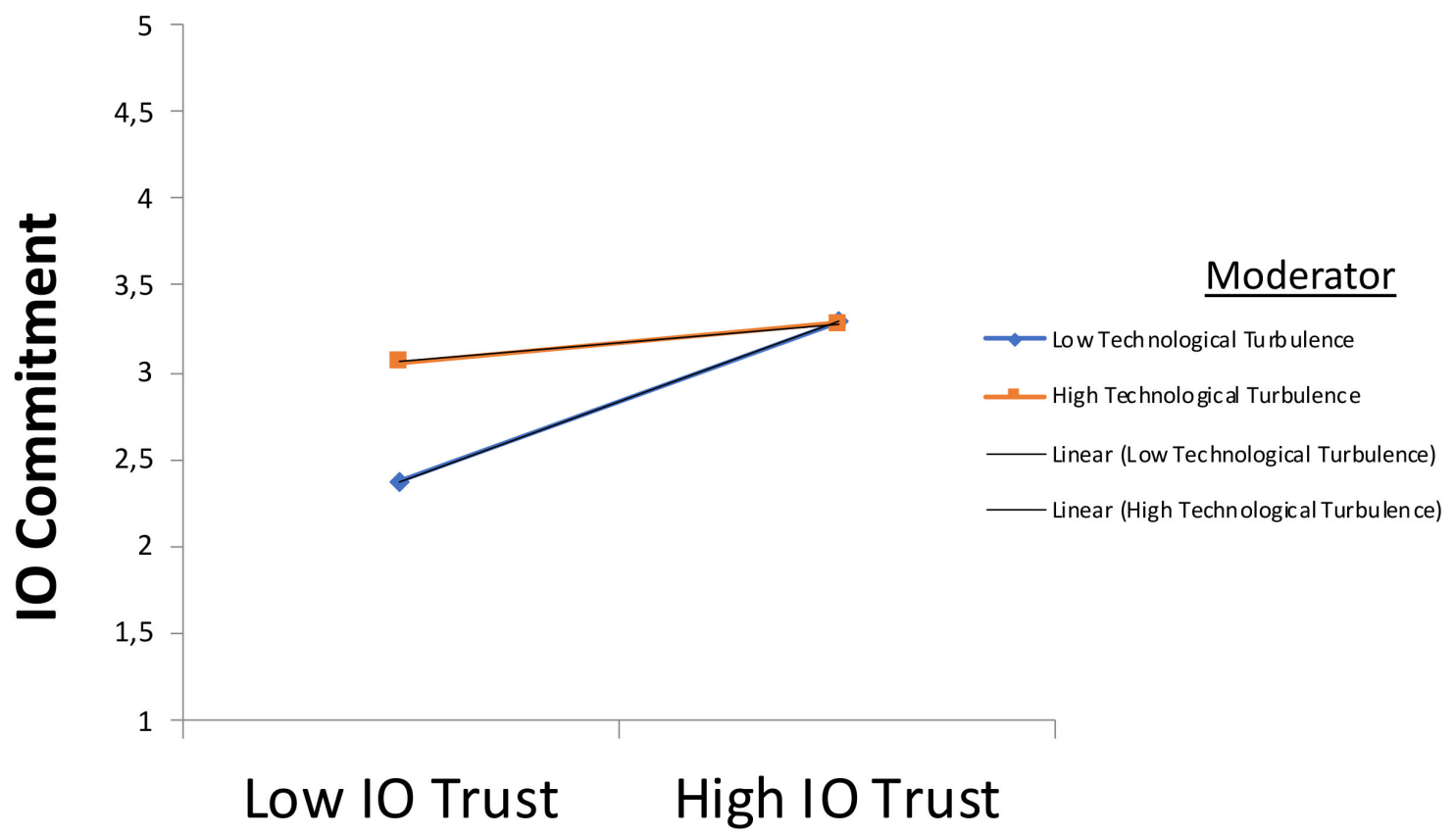

Figure 2. Technological turbulence as moderating effect

the importance of the close relationship that may decrease when the industry is affected by high technological turbulence (rapid technological change). Matanda and Freeman (2009) argue that technological (market) turbulence discourages commitment between buyers and suppliers. Moreover recent research (Pratono, 2018) argues that technological turbulence put aside past successful experiences for future practices.

In the context of high technological turbulence, as a business relationship may no longer be capable of driving more effective cooperation, NES may be considered to play a significant role in reversing the condition. NES shows a significant and positive influence on cooperation that is consistent with previous research (Svensson, et al., 2010). This present research finds that NES has the highest direct effect on cooperation. In the context of B2B ICT industry in Indonesia, when established cooperation becomes less effective, as in the case of high technological turbulence, non-economic satisfaction may revert and lead to future economic benefits (Dwyer et al., 1987; Geyskens and Steenkamp, 2000).
The indirect effects of interorganizational trust, interorganizational commitment, or interpersonal commitmenton cooperation show lowervalues. This finding concludes that non-economic satisfaction fully mediates between interorganizational trust and interorganizational commitment with cooperation. This result supports the argument of previous research (Svensson, et al., 2010) and recent research (Mungra and Yadav, 2020) that noneconomic satisfaction (satisfaction) may play a key mediation role between interorganizational trust and interorganizational commitment (trust/ commitment) with important outcome.

Result of this present research reveals that interpersonal relationship (interpersonal commitment) has positive and significant influence to building the organizational relationship (interorganizational commitment) and consistent with Mavondo and Rodrigo (2001). They argue that the interaction of members of an organization is building up interorganizational relationship. Interpersonal commitment displays the largest effect values, both direct and indirect. This finding supports the argument that interpersonal 
relationships may be a more effective relationship marketing (RM) strategy than customer-firm relationships (Palmatier, et al., 2006) and may prevent from partnerships failure (Phan, et al., 2005). Especially in a cross-cultural context, incorporating an interpersonal relationship into firms' RM strategy is critical. In the context of high technological turbulence, interpersonal relationships may revert partnership failure for more effective cooperation. The key construct interorganizational trust shows a positive and significant influence on interorganizational commitment in the context of B2B manufacturer-reseller ICT industry in Indonesia. This result is consistent with the arguments of Farrelly and Quester (2005), Ferro, et al. (2016), Hogevold, et al. (2020), Morgan and Hunt (1994), and Svensson, et al. (2010) that interorganizational trust proceeds interorganizational commitment. These two key constructs also show positive and significant influences on NES. The result is consistent with the arguments of Ferro, et al. (2016), Hogevold, et al. (2020), and Svensson, et al. (2010).

\section{MANAGERIAL IMPLICATIONS}

Besides contributing to the theoretical, this study also gives contribution to the industry in general and the RM managers in particular. Managers could rely on relationship marketing (RM) in driving more effective cooperation, as RM in the fast-changingtechnology B2B ICT industry Indonesia is still relevant. In low technological turbulence, managers could continue their RM strategy in driving cooperation. In high technological turbulence, as the turbulence may dampen the positive relationship between interorganizational trust and interorganizational commitment, managers could leverage non-economic satisfaction and interpersonal relationship to revert. Furthermore, developing interpersonal relationship should continuously be maintained by RM managers as it has significant and positive influence on interorganizational relationship.

\section{CONCLUSION}

The current study contributes to B2B relationship marketing stream. Firstly, the research examines the two-way interaction effect of technological turbulence as a moderating factor between the positive relationship of interorganizational trust and interorganizational commitment. Secondly, the research examines NES as a mediating role between interorganizational trust and interorganizational commitment with cooperation. Thirdly, the research examines interpersonal commitment as an antecedent of interorganizational commitment. Fourthly, the research examines relationship marketing characterized by interorganizational trust, interorganizational commitment, and noneconomic satisfaction in the fast-changingtechnology B2B ICT industry in Indonesia.

\section{Limitations and Suggestions}

Authors identify some limitations in the present study. First, NES as a mediating role is limited to the manufacturer-reseller relationship in B2B ICT industry in Indonesia. Future studies could consider other industries/countries for generalization purposes. Second, the present study examines one side of the dyad (resellers). Future studies could investigate both sides of the dyad (manufacturers/ makers and resellers). Third, the present study uses the cross-sectional nature of research design. Future studies could examine the manufacturer-reseller relationship from a longitudinal nature of research design to give better insights into the relationship progression. Fourth, the present study only tests technological turbulence as one factor of the quickly changing market conditions. Future studies could consider other market conditions that hold a positive relationship. 
Anderson, J.C. and Narus, J.A. (1990). A model of distributor firm and manufacturer firm working partnerships. Journal of Marketing, 54 (1), 42-58.

Chen, J., Neubaum, D.O., Reilly, R.R. and Lynn, G.S. (2015). The relationship between team autonomy and new product development performance under different levels of technological turbulence. Journal of Operations Management, 33, 83-96.

Christensen, C.M. (1993). The rigid disk drive industry: A history of commercial and technological turbulence. Business History Review, 67(4), 531-588.

Crosby, L.A., Evans, K.R. and Cowles, D. (1990). Relationship quality in services selling: an interpersonal influence perspective. Journal of Marketing, 54(3), 68-81.

Dwyer, F.R., Schurr, P.H. and Oh, S. (1987). Developing buyer-seller relationships. Journal of Marketing, 51(2), 11-27.

Farrelly, F.J. and Quester, P.G. (2005). Examining important relationship quality constructs of the focal sponsorship exchange. Industrial Marketing Management, 34(3), 211-219.

Ferro, Carlos, Carmen Padin, Göran Svensson, and Janice Payan. (2016). Trust and commitment as mediators between economic and non-economic satisfaction in manufacturer-supplier relationships. Journal of Business \& Industrial Marketing, 31(1), 13-23.

Garbarino, E. and Johnson, M.S. (1999). The different roles of satisfaction, trust, and commitment in customer relationships. Journal of Marketing, 63(2), 70-87.

Geyskens, I. and Steenkamp, J.B.E.. (2000). Economic and social satisfaction: measurement and relevance to marketing channel relationships. Journal of Retailing, 76(1), 11-32.

Geyskens, Inge, Jan-Benedict E. M. Steenkamp, and Nirmalya Kumar (1999). A Meta-Analysis of Satisfaction in Marketing Channel Relationships. Journal of Marketing Research, 36(20), 223-238.

Hair, J.F., Black, W.C., Babin, B.J. and Anderson, R.E. (2014). Multivariate Data Analysis (7 ${ }^{\text {th }}$ ed.). Pearson Education Limited.

Hogevold, N., Svensson, G. \& Otero-Neira, C. (2020). Trust and commitment as mediators between economic and noneconomic satisfaction in business relationships: a sales perspective. Journal of Business \& Industrial Marketing.

Jaworski, Bernard J., and Ajay K. Kohli (1993). Market Orientation: Antecedents and Consequences. Journal of Marketing, 57(3), 53-70.

Matanda, M.J. and Freeman, S. (2009). Effect of perceived environmental uncertainty on exporter-importer inter-organisational relationships and export performance improvement. International Business Review, 18(1), 89-107.

Mavondo, Felix T., and Elaine M. Rodrigo (2001). The effect of relationship dimensions on interpersonal and interorganizational commitment in organizations conducting business between Australia and China. Journal of Business Research, 52, 111121.

Moorman, C., Zaltman, G. and Deshpande, R. (1992). Relationships between providers and users of market research: The dynamics of trust within and between organizations. Journal of Marketing Research, 29(3), 314-328.

Morgan, Robert M. , and Shelby D. Hunt (1994). The Commitment-Trust Theory of Relationship Marketing. Journal of Marketing, 58(3), 20-38

Mungra, Y. and Yadav, P.K. (2019). The mediating effect of satisfaction on trust-commitment and relational outcomes in manufacturer-supplier relationship. Journal of Business \& Industrial Marketing, 35(2), 219-230.

Palmatier, R.W., Dant, R.P., Grewal, D. and Evans, K.R. (2006). Factors influencing the effectiveness of relationship marketing: A meta-analysis. Journal of Marketing, 70(4), 136-153.

Pratono, A.H. (2018). Does firm performance increase with risk-taking behavior under information technological turbulence? Empirical evidence from Indonesian SMEs. The Journal of Risk Finance, 19(4), 361-378.

Pesämaa, O., Pieper, T., Da Silva, R.V., Black, W.C. and Hair Jr, J.F. (2013). Trust and reciprocity in building inter-personal and inter-organizational commitment in small business co-operatives. Journal of Co-operative Organization and Management, 1(2), 81-92.

Phan, M.C., Styles, C.W. and Patterson, P.G. (2005). Relational competency's role in Southeast Asia business partnerships. Journal of Business Research, 58(2), 173-184.

Rodriguez, Ignacio Rodriguez del Bosque, Jesus Collado Agudo, and Hector San Martin Gutierrez (2006). Determinants of economic and social satisfaction in manufacturer-distributor relationships. Industrial Marketing Management, 35, 666675

Song, M., Droge, C., Hanvanich, S. and Calantone, R. (2005). Marketing and technology resource complementarity: An analysis of their interaction effect in two environmental contexts. Strategic Management Journal, 26(3), 259-276.

Svensson, G., Mysen, T. and Payan, J. (2010). Balancing the sequential logic of quality constructs in manufacturing-supplier relationships - Causes and outcomes. Journal of Business Research, 63(11), 1209-1214. 
Terawatanavong, C., Whitwell, G.J., Widing, R.E. and O'Cass, A. (2011). Technological turbulence, supplier market orientation, and buyer satisfaction. Journal of Business Research, 64(8), 911-918.

Tzempelikos, N. \& Kooli, K. (2018). Moderating effects of environmental uncertainty on behavioural intentions in business markets - a study across theoretical perspectives. Journal of Business \& Industrial Marketing, 33(7), 1037-1051.

Visentin, M. and Scarpi, D. (2012). Determinants and mediators of the intention to upgrade the contract in buyer-seller relationships. Industrial Marketing Management, 31(7), 1133-1141.

Wang, B., Childerhouse, P., Kang, Y., Huo, B. and Mathrani, S. (2016). Enablers of supply chain integration Interpersonal and interorganizational relationship perspectives. Industrial Management \& Data Systems, 116(4), 838-855.

Zaheer, Akbar, Bill McEvily, and Vincenzo Perrone (1998). Does Trust Matter? Exploring the Effects of Interorganizational and Interpersonal Trust on Performance. Organization Science, 9(2), 141-159. 
Table A1. Scale Items

\begin{tabular}{|c|c|c|c|}
\hline Construct & Items & $\begin{array}{c}\text { Factor } \\
\text { loadings }\end{array}$ & $\begin{array}{c}\text { Cronbach's } \\
\text { Alpha }\end{array}$ \\
\hline \multirow[t]{4}{*}{$\begin{array}{l}\text { Interorganizational } \\
\text { Trust (Zaheer et al., } \\
\text { 1998) }\end{array}$} & $\begin{array}{l}\text { Items are modified as follows: 'Supplier X' is replaced } \\
\text { with "Our major principals)." Definition of major } \\
\text { principal as 'your three principals with highest } \\
\text { contribution' is added. }\end{array}$ & & 0.70 \\
\hline & $\begin{array}{l}\text { 1. Our major principal has always been even-handed in } \\
\text { its negotiations with us. }\end{array}$ & 0.71 & \\
\hline & $\begin{array}{l}\text { 2. Based on past experience, we cannot with complete } \\
\text { confidence rely on our major principal to keep } \\
\text { promises made to us. (R) }\end{array}$ & 0.53 & \\
\hline & 3. Our major principal is trustworthy. & 0.90 & \\
\hline \multirow[t]{5}{*}{$\begin{array}{l}\text { Interorganizational } \\
\text { Commitment (Morgan } \\
\text { and Hunt, 1994) }\end{array}$} & $\begin{array}{l}\text { Items are modified as follows: 'supplier' is replaced } \\
\text { with 'principal'. Definition of major principal as 'your } \\
\text { three principals with highest contribution' is added. }\end{array}$ & & 0.83 \\
\hline & $\begin{array}{l}\text { 1. The relationship that my firm has with my major } \\
\text { principal is very important to my firm. }\end{array}$ & 0.63 & \\
\hline & $\begin{array}{l}\text { 2. The relationship that my firm has with my major } \\
\text { principal is of very little significance to my firm. (R) }\end{array}$ & 0.56 & \\
\hline & $\begin{array}{l}\text { 3. The relationship that my firm has with my major } \\
\text { principal is something my firm really cares about. }\end{array}$ & 0.79 & \\
\hline & $\begin{array}{l}\text { 4. The relationship that my firm has with my major } \\
\text { principal deserves our firm's maximum effort to } \\
\text { maintain. }\end{array}$ & 0.85 & \\
\hline \multirow[t]{5}{*}{$\begin{array}{l}\text { Interpersonal } \\
\text { Commitment } \\
\text { (Mavondo and } \\
\text { Rodrigo, 2001) }\end{array}$} & $\begin{array}{l}\text { Items are modified as follows: 'partner' is replaced with } \\
\text { 'contact person.' } \\
\text { Definition of contact person as 'salesperson, } \\
\text { channelperson or sales manager that works at major } \\
\text { principal' and major principal as 'your three principals } \\
\text { with highest contribution' is added. }\end{array}$ & & 0.79 \\
\hline & $\begin{array}{l}\text { 1. I provide valuable market information to my contact } \\
\text { person. }\end{array}$ & 0.51 & \\
\hline & $\begin{array}{l}\text { 2. The relationship I have with my contact person was } \\
\text { developed over a long period of time. }\end{array}$ & 0.62 & \\
\hline & $\begin{array}{l}\text { 3. I carry on developing my relationship with my } \\
\text { contact person so as to provide future advantages for } \\
\text { my company. }\end{array}$ & 0.84 & \\
\hline & $\begin{array}{l}\text { 4. I intend to exchange more important information } \\
\text { with my contact person. }\end{array}$ & 0.91 & \\
\hline \multirow[t]{4}{*}{$\begin{array}{l}\text { Cooperation (Mavondo } \\
\text { and Rodrigo, 2001) }\end{array}$} & $\begin{array}{l}\text { Cooperation } \\
\text { Items are modified as follows: 'partner' is replaced } \\
\text { with 'major principal' and 'changed circumstances' } \\
\text { added with information '(technology and business } \\
\text { model, such as: subscription, cloud-based, software } \\
\text { and managed services).' Definition of major principal } \\
\text { as 'your three principals with highest contribution' is } \\
\text { added. }\end{array}$ & & 0.80 \\
\hline & 1. My major principal exhibits similar goals to mine. & 0.68 & \\
\hline & 2. My major principal and I make decisions together. & 0.76 & \\
\hline & $\begin{array}{l}\text { 3. My major principal and I work together towards } \\
\text { common goals. }\end{array}$ & 0.83 & \\
\hline
\end{tabular}




\begin{tabular}{|c|c|c|c|}
\hline Construct & Items & $\begin{array}{l}\text { Factor } \\
\text { loadings }\end{array}$ & $\begin{array}{l}\text { Cronbach's } \\
\text { Alpha }\end{array}$ \\
\hline \multirow[t]{4}{*}{$\begin{array}{l}\text { Non-economic } \\
\text { Satisfaction } \\
\text { (Rodriguez, et al., } \\
2006 \text { ) }\end{array}$} & $\begin{array}{l}\text { Items are modified as follows: 'Bimbo Martinez' is } \\
\text { replaced with 'our major principal'. Definition of } \\
\text { major principal as 'your three principals with highest } \\
\text { contribution' is added. }\end{array}$ & & 0.77 \\
\hline & $\begin{array}{l}\text { 1. Our major principal is a good company to do } \\
\text { business with. }\end{array}$ & 0.80 & \\
\hline & $\begin{array}{l}\text { 2. We are happy with the products and services of our } \\
\text { major principal. }\end{array}$ & 0.69 & \\
\hline & $\begin{array}{l}\text { 3. We would recommend our major principal to our } \\
\text { customers. }\end{array}$ & 0.66 & \\
\hline \multirow[t]{4}{*}{$\begin{array}{l}\text { Technological } \\
\text { Turbulence (Jaworski } \\
\text { and Kohli, 1993) }\end{array}$} & $\begin{array}{l}\text { Items are modified as follows: 'our industry' is } \\
\text { replaced with 'business-to-business ICT industry' and } \\
\text { 'new product ideas' is replaced with 'new solutions/ } \\
\text { products.' }\end{array}$ & & 0.83 \\
\hline & $\begin{array}{l}\text { 1. The technology in business-to-business ICT industry } \\
\text { is changing rapidly }\end{array}$ & 0.75 & \\
\hline & $\begin{array}{l}\text { 2. Technological changes provide big opportunities in } \\
\text { business-to-business ICT industry }\end{array}$ & 0.77 & \\
\hline & $\begin{array}{l}\text { 3. A large number of new solutions/products have been } \\
\text { made possible through technological breakthroughs } \\
\text { in business-to-business ICT industry. }\end{array}$ & 0.88 & \\
\hline
\end{tabular}

Notes:

All items are measured with seven-point scale $(1=$ totally disagree and 7 = totally agree; $(\mathrm{R})$ denotes a reverse-coded item. 